\title{
The incidence of sudden death syndrome in a cohort of infants
}

\author{
Lorena T. C. Geib, ${ }^{1}$ Magda L. Nunes ${ }^{2}$
}

\begin{abstract}
Objectives: To quantify the incidence of sudden infant death syndrome in the town of Passo Fundo, in Rio Grande do Sul, Brazil, and to describe the profile of the deaths observed.

Methods: A population-based cohort study of the live births from February 2003 to January 2004 to parents resident in the urban area. Infants were excluded if they had been hospitalized since birth, were in the process of being adopted or had died before data collection. 2,411 children were included from the total of 2,634 live births and 2,285 (94.8\%) of these were followed-up. Data were obtained from the Live Births Information System (Sistema de Informações Sobre Nascidos Vivos), death registers, records of the Committee on Infant Mortality and from interviews with the social mother during home visits. Data collection instruments were adapted from previously validated forms. Data were analyzed on Epi-Info with descriptive statistics.

Results: Ten deaths were registered $(0.4 \%)$. Four deaths of unknown causes could be included in sudden infant death syndrome category III. These deaths took place at home, between 4 and 6 months of age. The children slept on their sides, sharing a bed with adults, and had soft mattresses, pillows and diapers on the surface. They were the children of young mothers, smokers, with incomplete prenatal care and previous births from underprivileged economic classes. The incidence of suspicion of this syndrome was 1.75/1,000.
\end{abstract}

Conclusion: The incidence rate of suspected sudden infant death syndrome in Passo Fundo is comparable with the highest international coefficients, which suggests the need for vigilance and risk prevention measures.

J Pediatr (Rio J). 2006;82(1):21-6: Infant mortality, epidemiology, prevention, sudden infant death syndrome (SIDS).

\section{Introduction}

Sudden infant death syndrome (SIDS) is in eighth position on the list of the causes of years of potential life lost and is the number one cause of postneonatal infant mortality in developed countries. ${ }^{1}$ The contribution to infant mortality made by SIDS in the Mercosul countries is unknown, with the exception of some capitals. ${ }^{2,3}$ Brazil is a country with a large population living in poor socioeconomic conditions, which are associated with SIDS, and yet there is a shortage of data on the incidence of $\operatorname{SIDS}^{4}$ with what data does exist referring to states in the South and Southeast of the country. 5

1. Doutora. Professora titular, Enfermagem, Universidade de Passo Fundo (UPF), Passo Fundo, RS, Brasil.

2. Professora adjunta, Faculdade de Medicina, Pontifícia Universidade Católica do Rio Grande do Sul (PUCRS), Porto Alegre, RS, Brasil.

Manuscript received Jun 24 2005, accepted for publication Aug 112005.

Suggested citation: Geib LT, Nunes ML. The incidence of sudden death syndrome in a cohort of infants. J Pediatr (Rio J). 2006;82:21-6.
The definition for SIDS that was established in 1969 was "the sudden death of any infant or young child, which is unexpected by history, and in which a thorough postmortem examination fails to demonstrate an adequate cause for death". 6

The following characteristics of SIDS have become apparent in many different countries: 1) a predominance of male victims at a proportion of $3: 2 ;^{7} 2$ ) approximately $90 \%$ of cases take place between one and 6 months, with a peak incidence between 2 and 4 months, when approximately two-thirds of deaths take place; 8 3 ) increased occurrence during winter, ${ }^{9}$ particularly in regions with low temperatures, ${ }^{10}$ which is possibly related to the quantity of bedclothes and swaddling used; ${ }^{11}$ 4) nocturnal occurrence predominates, with two-thirds of cases taking place between $22: 00$ and 07:30;12 5) higher incidence rates among African Americans and Indigenous peoples than among whites. Although there is variation in incidence rates across different populations, it is in Asia that the lowest rates of SIDS are observed, which may be 
strongly associated to the habit of putting infants down to sleep in the supine position; ${ }^{13}$ 6) underprivileged economic classes are just as susceptible to sudden death as to any other cause of infant mortality. ${ }^{14}$ In the case of SIDS, other factors have been associated with increased risk within these economic classes, including early motherhood, large families, smoking and drug abuse by mothers, prematurity, low birth weight and multiple births.

The lack of information on this syndrome tends to retard the implementation of educational and preventative measures and the identification of more vulnerable groups. This type of investigation should take account of the continental dimensions of the country (Brazil), and the great disparities in terms of climate, economy, society and culture between the different regions. The present study, taking such factors into account, proposes to quantify the incidence of SIDS in the town of Passo Fundo, in Rio Grande do Sul state, and to describe the mortality profile.

\section{Methodology}

This was a population cohort of 2,285 live births in Passo Fundo, Rio Grande do Sul. The town has a total population of 168,458 inhabitants, ${ }^{15}$ with $97.2 \%$ living in urban areas and $2.8 \%$ in rural areas and made up of $89 \%$ whites with no predominant ethnicity across Italians, Germans, indigenous races and others. The climate is temperate with humid, subtropical characteristics and a mean annual temperature of $17.5^{\circ} \mathrm{C} .16$ The municipal network for pediatric healthcare utilizes 24 basic healthcare units, eight family health program teams and all of the specialized healthcare units. ${ }^{17}$ The mean number of live births from 1996 to 2000 was 3,372 and the infant mortality coefficient was 18.73 deaths for every 1,000 live births in 2002 and 21.69 in 2003.18

\section{Study population}

All children born live to residents of the urban area were recruited from February 2003 to January 2004. Children born in Passo Fundo to parents residing in other districts were excluded (3\%), as were the children of residents of rural areas (3\%), infants hospitalized since birth $(0.26 \%)$, children who were adopted or in the process of adoption ( $0.57 \%)$ and children who died before data collection (1.6\%). Consequently, 2,411 children were recruited from the total of 2,634 live births. In a further $117(4.8 \%)$ of these cases it was not possible to locate the parents or guardians after three attempts at the addresses given on the Register of Births in the Live Births Information System (SINASC - Sistema de Informações sobre Nascidos Vivos), hospital and clinical records, or other community source of information, and nine families $(0.3 \%)$ refused to take part in the study. Overall, 2,285 liveborn infants (94.8\%) were followed-up for the first 12 months of their lives.

\section{Data collection}

Data were collected using a modified version of the instrument developed by Pinho ${ }^{19}$ to identify risk factors for SIDS in Porto Alegre - Rio Grande do Sul state, and from the Maternity Advice Survey, used in an international multicenter study (WHO/SIDS Global Strategy Force). 2,20

The initial source for data was the SINASC database, which provided sociodemographic and perinatal variables. Data related to children's previous history and sleeping habits were collected on home visits during interviews with the social mother (the woman who actually cares for the child, whether the biological mother or not). Economic status was assessed by the Brazilian Economic Classification Questionnaire (Critério de Classificação Econômica Brasil), ${ }^{21}$ which estimates the purchasing power of urban individuals and families, classifying them as follows, according to average family income (monthly): $A 1$ ( $R$ \$ $7,793), A 2(R \$ 4,648), B 1(R \$ 2,804), B 2(R \$ 1,669), C$ $(R \$ 927), D(R \$ 424)$ and $E(R \$ 207)$.

In order to quantify the incidence of suspected SIDS for the population of Passo Fundo, deaths were divided into those with confirmed causes (four cases) and unexpected ones (six cases). Just two infants in the unexpected deaths group had been submitted to autopsy; in one case the definition of "other unknown or unspecified causes of mortality" (ICD R99), while the other was diagnosed as "Unspecified event, undetermined intent" (ICD Y34.9). The remaining four were only examined clinically and the causes of death were recorded as indeterminate. Faced with this, the SIDS categories I, II and III $^{6}$ were used to classify unexplained deaths. Category III is aimed to facilitate epidemiological work in countries were autopsies are unlikely to take place or impossible and is a recommendation for the purposes of research and statistics, with no intention of generalizing or of substituting the 1969 definition, but in the Brazilian environment it can be of aid in improving both the diagnosis and epidemiology of this disease, which is considered under-diagnosed. 4 Notwithstanding, those cases that are subjected to autopsy and remain unsolved after careful investigation can be designated as deaths from unknown or unexplained causes, ${ }^{22}$ as took place in the present study.

Category I covers infant death that fulfills the generic criteria and also: age of 3 weeks to 8 months; no similar death among siblings, relatives who are close genetically, or other children in the charge of the same caregiver; no evidence indicating trauma, abuse, neglect or significant accident; no evidence of unexplained, moderate or severe, stress to the thymus or supra-renal glands or to other tissues or organs. 
Category II, covers infant deaths that fulfill the criteria for Category I SIDS, plus one or more of the following characteristics: less than one year, but outside of the 3 weeks to 8 months range; similar deaths of siblings or other family members closely related genetically, with no suspicion of infanticide (demonstrated by genetic orientation); inflammatory or other abnormalities that are more severe than for Category I SIDS, but insufficient to be a cause of death. This Category also includes cases in which mechanical asphyxia is considered a possibility, but not a certainty, and which must be based on strong evidence.

After coding, data were input by two independent typists onto Excel databases, (Office 2000, Microsoft). Monthly the researcher crosschecked the databases against each other and with the original forms, identifying errors of amplitude and consistency and making any corrections that proved necessary. The team supervisor repeated $7.5 \%$ of interviews for quality control, and the level of intraobserver agreement was very good [Kappa $=0.86$ (95\% CI: 0.78-0.94)].

Data was analyzed on Epi-Info, version 6.0, using descriptive statistics.

The research project was approved by the Passo Fundo Municipal Health Secretariat and by the Committee for Ethics in Research at the Pontifícia Universidade Católica in Rio Grande do Sul. Each participant, or legal guardian of the infant, received a free and informed consent form, which they signed if they agreed to participate.

\section{Results}

There were ten deaths among the 2,285 infants $(0.4 \%)$. Four were registered as of unknown causes $(1,2,6$ and 8$)$ and number 10 (Table 1 ) was also put into this group because no autopsy was performed that could have confirmed a basic cause of death and also because there was a strong suspicion of SIDS. The last four of these five infants died at home and were taken to an emergency service where death was confirmed; four were classed as economic status $\mathrm{E}$ one as $\mathrm{D}$; all of them were sharing a bed with their parents at the time of death (one was sharing with five other people); they always slept in decubitus lateral; three were male; they were aged from 2 to 5 months (the ages of the children who died from defined were 3, 6 and 8 months) and their mothers' ages varied from 16 to 27 years. Two were young mothers (16 and 20 years old), all had less than 8 years' schooling. Two had attended less than six prenatal consultations. Three smoked during the pregnancy, one of whom consumed 50 cigarettes a day. None of the victims was born prematurely; mean birth weight was $2,758 \mathrm{~g}(\mathrm{SD}=409)$. All were cared for by their own mothers, were clothed and wrapped up appropriately for the weather, but half slept on soft mattresses with diapers on them; the other half slept on intermediate mattresses; all used pillows. Half had been weaned completely before the end of their first month of life and habitually did not use pacifiers. There was no information on siblings, closely genetically related family members or other children in the charge of the same caregiver. The records consulted did not contain any evidence indicative of trauma, abuse, negligence or significant accidents.

The descriptions of the deaths in the records of the Committee on Infant Mortality allow cases 2, 6, 8 and 10 to be defined as unexpected deaths that can be included in Category III SIDS. ${ }^{6}$ Based on these, the incidence of suspected SIDS in the town of Passo Fundo is calculated to be $1.75 / 1,000$ for 2003 .

\section{Discussion}

When interpreting these results certain limitations should be taken into consideration. These are related to the following methodological aspects: 1) the inclusion of unexplained deaths in Category III SIDS, ${ }^{6}$ which allowed an incidence of "suspected" SIDS to be calculated. Even so, the data obtain serve to highlight the need for autopsies and for professionals with specific training for postmortem diagnosis, which will contribute towards improving data; 2) the quantification of the incidence of the restricted syndrome in the year 2003, which meant that the sample had no statistical power for establishing causality; nevertheless, the description of the profiles of the deaths occurred provides some information to guide preventative activities; 3 ) the exclusion of neonatal and postneonatal deaths before 2 months of age, which may have contributed to a selection bias, if it weren't for the separate analysis of this period to check for unexplained deaths. None were found.

In Brazil, SIDS does not appear on official statistics and autopsy is not obligatory, both factors which could be obscuring both the identification and distribution of SIDS. The three Brazilian studies found in the literature limit themselves to the syndrome's epidemiology in the Southeast and South regions of Brazil. The first described the infant mortality of a cohort of 5,914 live births in the town of Pelotas (RS) in 1982-1983, and identified that $11 \%$ of infant deaths were from unknown or unspecified causes, $4 \%$ of which were probable cases of SIDS. ${ }^{23}$ The second study was a retrospective analysis of 344 autopsies of expected deaths and 25 unexpected ones $(n=369)$ from January 1987 to December 1990 in Ribeirão Preto, São Paulo state, identifying ten cases with characteristics similar to SIDS among the unexpected deaths of children aged from one to 3 months. In eight of these cases the autopsy diagnosis was aspiration, one case was SIDS and the last remained undiagnosed. ${ }^{5}$ The third study, also 
Table 1 - Infant deaths of the cohort according to sex, age and cause, with description of clinical history

\begin{tabular}{|c|c|c|c|c|c|c|}
\hline Patient & Sex & Age & Death cause* & ICD 10 & Necropsy & Review of clinical history \\
\hline 1 & M & $4 m$ & Indeterminate & R99 & No & $\begin{array}{l}\text { Cardiorespiratory arrest (CRA) at the emergency room. } \\
\text { Resuscitation. Referred to Intensive Care Unit (ICU). } \\
\text { Pale, acyanotic, bilateral rales, sub and intercostal } \\
\text { retraction. Premature, hyalin membrane, } \\
\text { bronchopulmonary dysplasia. }\end{array}$ \\
\hline 2* & $\mathrm{F}$ & $4 \mathrm{~m} 20 \mathrm{~d}$ & Indeterminate & R99 & Yes & $\begin{array}{l}\text { After waking up in the morning, the mother realized } \\
\text { the child was hypotonic and did not breath. } \\
\text { At the emergency room arrival she was with CRA } \\
\text { and cadaveric stiffness. }\end{array}$ \\
\hline 3 & $\mathrm{~F}$ & $2 \mathrm{~m} 15 \mathrm{~d}$ & $\begin{array}{l}\text { Unspecified } \\
\text { bronchopneumonia }\end{array}$ & $\mathrm{J} 18.0$ & No & $\begin{array}{l}\text { CRA at emergency room. Resuscitated. Transferred to } \\
\text { the ICU. Pale, acyanotic, bilateral rales, } \\
\text { sub and intercostal retraction. Premature, } \\
\text { hyalin membrane, bronchopulmonary dysplasia. }\end{array}$ \\
\hline 4 & M & $4 m$ & Indeterminate & R99 & No & $\begin{array}{l}\text { Referred to the emergency room with cough and diarrhea } \\
\text { for two days. After } 3 \text { hours returns with fever, } \\
\text { no findings at clinical examination, no administration } \\
\text { of drugs. After } 12 \text { hours returns to hospital with CRA, } \\
\text { muscular stiffness and hypotonia. }\end{array}$ \\
\hline 5 & M & $8 m$ & $\begin{array}{c}\text { Bowel } \\
\text { invagination }\end{array}$ & K56.1 & No & $\begin{array}{l}8 \text { months. Several hospital stays. Last hospital stay: } \\
\text { acute respiratory infection and subglottic stenosis, } \\
\text { intestinal occlusion. Submitted to enterectomy and } \\
\text { enteroanastomosys. Hemophilic anemia. }\end{array}$ \\
\hline 6* & M & $3 \mathrm{~m} 15 \mathrm{~d}$ & $\begin{array}{l}\text { Unspecified } \\
\text { facts or events } \\
\text { and indetermined } \\
\text { intention }\end{array}$ & Y34.9 & Yes & $\begin{array}{l}\text { Arrives at the emergency room with CRA, rigid, mydriasis, } \\
\text { cyanotic. Great amount of milk in the lungs. }\end{array}$ \\
\hline 7 & M & $7 \mathrm{~m} 17 \mathrm{~d}$ & $\begin{array}{l}\text { Unspecified } \\
\text { heart } \\
\text { malformation }\end{array}$ & Q24.9 & No & $\begin{array}{l}\text { At the fourth ICU stay, presented CRA, failed } \\
\text { resuscitation. Hospital stay for BCP. Heart failure } \\
\text { diagnose. High ventilatory patterns. }\end{array}$ \\
\hline $8^{*}$ & M & $3 m$ & Indeterminate & R99 & No & $\begin{array}{l}\text { The mother found the child in the cradle, not breathing, } \\
\text { cyanotic, cold extremities. Arrived at the emergency } \\
\text { with CRA. Failed resuscitation. }\end{array}$ \\
\hline 9 & M & $3 \mathrm{~m} 20 \mathrm{~d}$ & $\begin{array}{l}\text { Unspecified } \\
\text { bronchopneumonia }\end{array}$ & $\mathrm{J} 180$ & Yes & $\begin{array}{l}\text { After morning breastfeeding the infant was found with } \\
\text { CRA. Necropsy: presence of milk in the upper airways } \\
\text { and pneumonia. }\end{array}$ \\
\hline $10 *$ & $\mathrm{~F}$ & $4 \mathrm{~m} 05 \mathrm{~d}$ & $\begin{array}{l}\text { Cardiorespiratory } \\
\text { arrest }\end{array}$ & R092 & No & $\begin{array}{l}\text { The baby was bottle fed at dawn. At } 12 \text { p.m. the mother } \\
\text { realized the child was dead. Referred to hospital with } \\
\text { cadaveric stiffness and CRA. }\end{array}$ \\
\hline
\end{tabular}

* Cases with suspicion of sudden infant death syndrome (SIDS).

retrospective, revised questionnaires applied by the Municipal Health Secretariat's Mortality Vigilance Program (Prá Viver - To Live) and the autopsy reports by the Instituto Médico Legal in Porto Alegre, finding that 21 of the 335 infant $(36.8 \%)$ were compatible with the SIDS classification, although this diagnosis was not recorded as the cause of death in any of them. The specific mortality coefficient was estimated at 4.5/10,000 live births. ${ }^{19}$
The infant mortality coefficient in Passo Fundo in 2003 was 21.69 , above the statewide coefficient of 15.9. These indicators have been stable from 2000 through 2003. The $10(0.4 \%)$ infant deaths in the cohort confirm that the postneonatal component (6.47) in the town is lower than the neonatal component (15.2). ${ }^{18}$

None of the four unexpected deaths was registered as "sudden death" (ICD R.95), despite a review of the 
circumstances of death and the clinical history investigated and recorded by the Committee on Infant Mortality strongly suggesting this diagnosis as cause of death. These signs alone would be sufficient motive for performing a complete autopsy, which would aid in confirming diagnosis. Nevertheless, just two of the deaths from indeterminate causes were the subject of autopsies and one of these remained in the category "other unknown or unspecified causes of mortality" (ICD R99). In common with the findings of underdiagnosis made by studies in Pelotas, Ribeirão Preto and Porto Alegre, mentioned earlier, in Passo Fundo the tendency was the same. In response to this, the information obtained was applied to the system of SIDS sub-definitions ${ }^{6}$ so that an incidence of suspected SIDS could be calculated for the town. This figure was 1.75/1,000 live births.

Against the background of double-figure Brazilian infant mortality coefficients, the rate observed in Passo Fundo might appear insignificant. However, if the postneonatal mortality component is analyzed, probable SIDS cases account for $40 \%$, which alone would justify specific preventative actions aimed at the control of identified risk factors. In comparison with international rates, this coefficient is comparable with developed countries ( 0.7 and $1 / 1,000$ live births), ${ }^{24}$ suggests serious measures for vigilance and risk prevention are needed.

The unexpected deaths occurred during the window of vulnerability to SIDS ( 2 to 5 months) and also combined certain characteristics of the disease, such as death at home and underprivileged economic class. Furthermore, the following characteristics were observed: a) related to maternal factors: smoking during pregnancy, early maternity (<20 years), multiparity and insufficient number of prenatal consultations; b) related to the infant: low birth weight, early weaning and no pacifier; c) related to sleeping habits: sleeping on side, bed sharing, habitual use of bedclothes and bedding that have a potential for $\mathrm{CO}_{2}$ re-inhalation (soft mattress, pillow, diaper on surface); d) related to economic status: classes $\mathrm{D}$ and $\mathrm{E}$.

The relationship between risk factors by which they multiply each other is well known, particularly with respect of bed sharing and smoking, ${ }^{25}$ both observed in this study. This last, together with maternal age of less than twenty, were the primary risk factors for SIDS identified in Porto Alegre. ${ }^{19}$ After decubitus ventral - a practice very little employed in Passo Fundo and Porto Alegre -, smoking is the most important independent risk factor for SIDS with an attributable risk of $37 \% .{ }^{26}$ The risk is dose-dependent, being eight times greater in heavy smokers ( + of 20 cigarettes/day). The death from this cohort that was registered as "cardiorespiratory arrest" and that was better fitted to category III SIDS, took place in association with bed sharing, and smoking 50 cigarettes/day during pregnancy and economic status E.
The risk of bed sharing with multiple bedfellows and the risk of soft surfaces have also been well established, 27 both found in one of the cases of unexpected death in which the infant shared the bed with its mother and five other members of the family on a medium density mattress with a pillow and a diaper on the surface.

Social variables such as reproductive age of less than 20 years, little education and underprivileged economic class, together with insufficient prenatal care, assume priority status through this study as the targets for planning and intervention to reduce the risk of infant mortality. Factors such as poverty, low levels of education, deficient intrauterine nutrition and smoking during pregnancy, all observed in this cohort, are determinants of infant mortality, whatever the pathological processes dictating the outcome may be. In recognition of their social impact, they merit urgent and effective action, such as the insertion of educational groups for self-sustainability and health, realizing the potential of the municipal health networks, education and social work.

In synthesis, the incidence rate of suspected SIDS in Passo Fundo in 2003 was comparable with coefficients in developed countries. Its proportion of the postneonatal component suggests the need for prevention of adolescent pregnancy, early and continued involvement of expectant mothers in prenatal care, control of smoking during pregnancy, encouragement of maternal breastfeeding and guidance on healthy infant sleeping habits.

\section{References}

1. McVea KL, Turner PD, Peppler DK. The role of breastfeeding in sudden infant death syndrome. J Hum Lact. 2000;16:13-20.

2. Cafferata ML, Althabe F, Belizán JM, Cowan S, Nelson EA, MAS Study Group para América Latina y el Caribe. Posición al dormir en hospitales de América Latina y el Caribe para la prevención del síndrome de muerte súbita del lactante. Ann Esp Pediatr. 2002; $57: 558-64$.

3. Gutiérrez CA, Palenzuel S, Rodrigues A, Balbela B, Rubio I, Lemes $A$, et al. Muerte inesperada del lactante. Diagnóstico de situación en la ciudad de Montevideo. Rev Chil Pediatr. 2003; 74: 215-29.

4. Nunes ML, Pinho AP, Aerts D, Sant'Anna A, Martins PM, da Costa JC. Sudden infant death syndrome: clinical aspects of an underdiagnosed disease. J Pediatr (Rio J). 2001;77:29-34.

5. Peres LC. Sudden unexpected infant death syndrome in Ribeirão Preto, Brazil. Rev Paulista Med. 1998;116:1803-7.

6. Beckwith JB. Defining the sudden infant death syndrome. Arch Pediatr Adolesc Med. 2003;157:286-90.

7. Carolan P. Sudden infant death syndrome. Emedicine. http:// www.emedicine.com/ped/topic2171.htm. Access: 13/2/2004.

8. American Academy of Pediatrics. Task force on infant sleep position and sudden infant death syndrome. Changing concepts of sudden infant death syndrome: implications for infant sleeping environment and sleep position. Pediatrics. 2000;105:650-6.

9. Paris CA, Remler R, Daling JR. Risk factors for sudden infant death syndrome: changes associated with sleep position recommendations. J Pediatr. 2001;139:771-7.

10. Fleming $P$, Blair $P$, Sawczenko $A$. Sudden infant death syndrome: modifiable risk factors and the window of vulnerability. In: Loughlin GM, Carrol JL, Marcus CL, editors. Sleep and breathing in children: a developmental approach. New York: Marcel Dekker Inc; 2000. p. 443-64. 
11. Gutiérrez CA. Síndrome de la muerte súbita del lactante. Medicina de Família.net. 2001. http://www.zonadesalud.org. Access: $14 / 2 / 2004$.

12. Williams SM, Mitchell EA, Taylor BJ. Are risk factors for sudden infant death syndrome different at night? Arch Dis Child. 2002;87:274-8.

13. Nelson EA, Taylor BJ, ICCPS Group. International child care practices study: infant sleep position and parental smoking. Early Hum Dev. 2001;64:7-20.

14. Taylor JA, Sanderson M. A re-examination of the risk factors for the sudden infant death syndrome. J Pediatr. 1995;126:887-91.

15. Fundação Instituto Brasileiro de Geografia e Estatística. Censo demográfico. 2000. http://www.ibge.gov.br. Access: 14/7/ 2004.

16. Prefeitura Municipal de Passo Fundo. Mapa 2003. Passo Fundo: Secretaria Municipal de Educação, Secretaria Municipal de Turismo, Cultura e Desporto; 2003.

17. Prefeitura Municipal de Passo Fundo. Unidades de Saúde. Passo Fundo: Secretaria Municipal de Saúde; 2004. http.www.pmpf.rs. gov.br. Access: 15/7/2004.

18. Prefeitura Municipal de Passo Fundo. Mortalidade infantil 20032004. Passo Fundo: Secretaria Municipal da Saúde; 2004. Relatório técnico.

19. Pinho AS. Fatores de risco da síndrome da morte súbita do lactente [dissertação]. Porto Alegre: Pontifícia Universidade Católica do Rio Grande do Sul; 2001.

20. Nunes ML, Martins MP, Nelson EA, Cowan S, Cafferata ML, da Costa JC. Orientações adotadas nas maternidades dos hospitaisescola do Brasil, sobre posição de dormir. Cad Saude Publica. 2002; $18: 883-6$.
21. Associação Brasileira de Empresas de Pesquisa. Critério de classificação econômica Brasil. http://www.anep.org.br/ codigosguias/CCEB.pdf 2002. Access: 24/9/2004.

22. American Academy of Pediatrics: Distinguishing sudden infant death syndrome from child abuse fatalities. Pediatrics. 2001; 107:437-41.

23. Barros F, Victora CG, Granzoto JA, Vaughan JP, Lemos Jr AV. Saúde perinatal em Pelotas, RS, Brasil: fatores sociais e biológicos. Rev Saude Publica. 1984;18:301-12.

24. SIDS Global Strategy Task Force. International Statistics. SIDS International. 2000. http://www.sidsinternational.minerva. com.au. Access: 18/8/2004.

25. James $C$, Klenka H, Manning D. Sudden infant death syndrome: bed sharing with mothers who smoke. Arch Dis Child. 2003;88: 112-3.

26. Hauck FR, Herman SM, Donovan M, Iyasu S, Merrick MC, Donoghue $E$, et al. Sleep environment and the risk of sudden infant death syndrome in an urban population: the Chicago Infant Mortality Study. Pediatrics. 2003;111:1207-14.

27. Person TL, Lavezzi WA, Wolf BC. Cosleeping and sudden unexpected death in infancy. Arch Pathol Lab Med. 2002;126:345.

Correspondence:

Lorena Teresinha Consalter Geib

Rua Tiradentes, 400/601, Centro

CEP 99010-260 - Passo Fundo, RS - Brazi

Tel.: + 55 (54) 313.5206

E-mail: Iorena@upf.br 